\title{
Pengaruh Sistem Informasi Sumber Daya Manusia Terhadap Kinerja Pada Pegawai PT Raudah Utama Cianjur
}

\author{
Andri Asoka Sidantara Rosadi, Yudiyanto Joko Purnomo
}

Fakultas Ekonomi Universitas Nasional Pasim

Email corresponding author: andriaox@gmail.com/joko.jember 2015@gmail.com

\begin{abstract}
ABSTRAK
PT Raudah Utama Cianjur adalah sebuah travel agent yang melayani perjalanan dalam dan luar negeri, yang mana PT Raudah Utama Cianjur ini membuka kantor Haji, Umroh, Tour dan Tiket di Kota Cianjur, untuk memenuhi dan memberikan pilihan kepada masyarakat Cianjur dan sekitarnya dalam kebutuhan perjalanan Dinas serta lainnya, dengan konsep dasar melayani dan memuaskan para konsumen yang akan menggunakan jasa travel agent ini. Fenomena yang terjadi pada PT. Raudhah Utama Cianjur adalah . 1). Pelaksanaan sistem informasi SDM telah diaplikasikan dengan baik. 2). Pegawai sudah memahami tata laksana peraturan kerja dengan sistem digital yang telah diberlakukan oleh perusahaan, sehingga kedua belah pihak baik pegawai dan perusahaan mendapatkan manfaat positif dari Sistem Informasi Manajemen Sumber daya Manusia. 3). Pencapaian target rata-rata mencapai hasil yang optimal meskipun dengan beberapa penyimpangan yang tidak terukur menyebabkan target kerja tidak tercapai. Metode penelitian yang digunakan dalam penelitian ini adalah metode deskriptif dan metode asosiatif.Dalam penelitian ini yang menjadi unit analisis adalah individu, yaitu pegawai PT. Raudah Utama Cianjur. Populasi dari penelitian ini adalah pegawai yang berjumlah 30 Orang. Teknik penarikan sampel dalam penelitian ini menggunakan sensus atau sampling jenuh. metode pengumpulan data ini terdiri dari wawnncara, kuesioner dan observasi.
\end{abstract}

Kata Kunci: Sistem informasi, kinerja pegawai

\section{PENDAHULUAN}

Proses pelayanan didominasi oleh manusia, sementara hubungan antar sistem di dalam organisasi yang merupakan prasyarat tercapainya organisasi yang efektif secara langsung membutuhkan kemampuan pengelolaan sumber daya manusia yang lebih baik pula. Perusahaan yang dinamis akan selalu meningkatkan produktivitasnya melalui konsistensinya untuk menghasilkan kinerja terbaik serta mempertahankan aspek yang menjadi keunggulan kompetitif tersebut. Faktor yang dianggap paling potensial dalam penyediaan keunggulan kompetitif bagi perusahaan adalah Sumber Daya Manusia, serta terkait dengan bagaimana mengelola sumber daya ini. (Suwatno. 2011) Unsur manusia yang memegang peranan penting dan sangat menentukan keberhasilan organisasi tersebut. Kemampuan SDM akan sangat berpengaruh terhadap kemajuan perusahaan. (Sidharta \& Lusyana, 2014) Bahkan Rivai (2009) menyatakan penilaian kinerja merupakan hasil kerja pegawai dalam lingkup tanggung jawabnya. Dengan kata 
lain penilaian kinerja pegawai bisa dilihat dari bagaimana hasil dari pencapaian kinerja perusahaannya.

Strategi organisasi atau perusahaan yang kompetitif akan dapat dirumuskan melalui berbagai masukan dari sumber daya manusia dan hal ini menjadi dasar dalam penyusunan perencanaan sumber daya manusia (human resources planning). Hal ini dapat diwujudkan melalui proses yang didukung instrumen kebijakan dengan melakukan analisis dan identifikasi kebutuhan sumber daya manusia serta ketersediannya. Tindakan dari proses tersebut melalui tahapan pemeriksaan atau audit sumber daya manusia, agar diperoleh dasar keputusan terhadap kondisi objektif atas berbagai permasalahan strategi dalam kebutuhan sumber daya manusia yang direncanakan.

Dinamika kinerja perusahaan terjadi karena disebabkan oleh faktor yang mempengaruhinya. Pada umumnya kinerja perusahaan yang optimal dipengaruhi oleh faktor internal maupun eksternal. Faktor internal yang diduga kuat memberikan pengaruh terhadap kinerja perusahaan saat ini adalah dukungan Sistem informasi SDM yang juga berpengaruh terhadap Kinerja.

Di berbagai perusahaan, pemanfaatan Sistem Informasi Sumber Daya Manusia (Human Resource Information Sistem) mampu meningkatkan kinerja dan daya saing usaha. Terutama ketika perusahaan membutuhkan informasi yang cepat dan tepat, dan ketika perusahaan membutuhkan ketersediaan data untuk proses pengambilan keputusan. Hubungan antara kinerja dan Sistem Informasi Sumber daya manusia dijelaskan oleh Anshory (2009) bahwa penguasaan teknologi informasi merupakan tuntutan yang mutlak pada suatu perusahaan. Hal terlihatpada sebagian besar perusahaan yang telah menggunakan sistem informasi manajemen dalam melaksanakan kegiatan operasional perusahaan. Seluruh pegawai perusahaan diwajibkan menguasai sistem informasi sesuai dengan kebutuhan departemennya masing masing. Sistem Informasi SDM sebagai suatu sistem informasi terintergrasi yang dirancang untuk meningkatkan efisiensi dengan mengumpulkan data SDM dan untuk membuat dokumen SDM lebih berguna sebagai sumber informasi. (Mathis, 2009). Dengan demikian bisa dikatakan bahwa langkah-langkah aktivitas MSDM terangkum dan terstandarisasi dalam aplikasi pengelolaan sumber daya yang berdampak pada kinerja perusahaan PT Raudah Utama Cianjur sebagai perusahaan perjalanan wisata dengan menggunakan standar service, grooming, dan Gesture.PT Raudah Utama Cianjur telah memanfaatkan teknologi yang berbasiskan sistem informasi, perusahaan telah menciptakan suatu sistem, dengan konsep yang berpatokan pada service excellent yang didukung oleh pelayanan prima pada pelanggan sehingga pelayanan terhadap customer tetap dapat diberikan secara maksimal. Pelayanan yang dimaksud merupakan pembeda antara perusahaan yang satu dengan yang lainnya. Produk dan harga akan tampak bersaing, tetapi dengan pelayanan jelas akan membedakannya 


\section{TINJAUAN PUSTAKA}

\section{Manajemen Sumber Daya Manusia}

Menurut Sedarmayanti (2010: 5) Manajemen sumber daya manusia adalah suatu ilmu atau cara bagaimana mengatur hubungan dan peranan sumber daya (tenaga kerja) yang dimiliki oleh individu secara efisien dan efektif serta dapat digunakan secara maksimal sehingga tercapai tujuan (goal) bersama perusahaan, pegawai dan masyarakat menjadi maksimal. MSDM didasari pada suatu konsep bahwa setiap pegawai adalah manusia bukan mesin dan bukan semata menjadi sumber daya bisnis, berikut ini merupakan beberapa pengertian manajemen sumber daya manusia dari beberapa ahli.

Menurut Malayu S.P.Hasibuan (2012: 10) Manajemen Sumber Daya Manusia adalah ilmu dan seni mengatur hubungan dan peranan tenaga agar efektif dan efisien membantu terwujudnya tujuan perusahaan, pegawai, dan masyarakat.

Manajemen Sumber Daya Manusia menurut Marwansyah (2010:3), manajemen sumber daya manusia dapat diartikan sebagai pendayagunaan sumber daya manusia di dalam organisasi, yang dilakukan melalui fungsi-fungsi perencanaan sumber daya manusia, rekrutmen dan seleksi, pengembangan sumber daya manusia, perencanaan dan pengembangan karir, pemberian kompensasi dan kesejahteraan, keselamatan dan kesehatan kerja, dan hubungan industrial.

Berdasarkan pengertian di atas penulis menyimpulkan bahwa betapa demikian pentingnya manajemen sumber daya manusia di dalam mencapai tujuan perusahaan, pegawai dan masyarakat, dimana pendayagunaan sumber daya manusia di dalam organisasi tersebut dilakukan melalui fungsi-fungsi yang dibutuhkan dalam sumber daya manusia.

\section{Sistem Informasi Sumber Daya Manusia}

Sistem informasi sumber daya manusia merupakan proses kegiatan mengiventarisir kondisi, keadaan sumber daya manusia yang berada di dalam perusahan untuk mengetahui kuantitas dan kualitas maupun permasalahan yang dihadapi untuk menjadi bahan pertimbangan dalam pengambilan kebijaksanaan manajemen sumber daya manusia. Sistem ini merupakan suatu prosedur yang sistematis untuk mengumpulkan, menarik, menyimpan, dan memutakhirkan data yang dibutuhkan suatu perusahaan tentang sumber daya manusia

Sistem informasi SDM Menurut Veithzal Rivai (2009;1015) merupakan prosedur sistematik untuk pengumpulan, menyimpan, mempertahankan, menarik, memvalidasi data yang dibutuhkan oleh sebuah perusahaan untuk meningkatkan keputusan SDM. Selanjutnya dimensi yang digunakan dalam penelitian ini adalah 1). Pengumpulan data, 2). Menyimpan data, 3). Mempertahankan data, 4). Menarik data, 5) memvalidasi data 6). Pengambilan keputusan SDM 


\section{Karakteristik Sistem Informasi Sumber Daya Manusia}

Menurut Henry Simamora (2009:90) dalam bukunya manajemen sumber daya manusia mengungkapkan bahwa "Sebuah sistem informasi sumber daya manusia haruslah di rancang untuk menyediakan informasi", yaitu :

Karakteristik sistem informasi sumber daya manusia di atas dapat diuraikan secara ringkas sebagai berikut :

1. Tepat waktu - Manajer harus memiliki akses untuk memutakhirkan informasi. Informasi yang disajikan kepada manajer haruslah memiliki ketetapan waktu pada saat inforrmasi tersebut disajikan sehingga proses pengambilan keputusan dapat dilakukan dengan baik, selain itu informasi harus selalu up to date, diterapkan pada waktu yang layak dan sampai pada alokasi yang tepat.

2. Akurat - Manajer haruslah mampu bergantung pada keakuratan informasi yang disediakan.

3. Informasi yang dibutuhkan pemakai harus memenuhi tingkat akurasi atau ketepatan yang tinggi, bebas dari pengertian yang menyesatkan, kesalahan material, dan dapat diandalkan oleh pemakainya Ringkas - Manajer dapat menyerap banyak informasi yang dibutuhkan dalam situasi - situasi tertentu. Informasi yang disajikan tersebut tidak berbelit - belit dan memuat substansi inforrmasi yang dibutuhkan dalam situasi tertentu.

4. Relevan- Manajer haruslah hanyamen dapatkan, informas yang dibutuhkan dalam situasi tertentu. Relevansi suatu informasi harus dihubungkan dengan maksud penggunaannya, para pemakai informasi hanya mendapatkan informasi yang dibutuhkan dalam situasi tertentu.

5. Lengkap - Manajer haruslah mendapatkan informasi yang lengkap dan tidak terpotong - potong. Informasi yang disajikan tidak terpotong - potong, meliputi semua aspek yang berkaitan dengan daya guna informasi tersebut bagi pemakai.

\section{Sumber Sistem Informasi Sumber Daya Manusia}

Membentuk sistem sumber daya manusia yang komprehensif memerlukan informasi yang diperoleh dari berbagai sumber. Formulir - formulir khusus dan kuesioner - kuesioner dapat dibuat untuk mengumpulkan informasi bagi keperluan sistem informasi sumber daya manusia, seperti diungkapkan oleh Henry Simamora (2009:94) sebagai berikut :

1. Blangko - Blangko lamaran haruslah dirancang guna mempermudah mengumpulkan informasi yang dibutuhkan untuk sistem informasi sumber daya manusia. Informasi ini mencakup tingkat pendidikan, keahlian, dan data biografis lainnya yang relevan. Setelah si calon diseleksi, calon diminta menyelesaikan blangko kedua yang meminta informasi lebih rinci untuk keperluan sistem informasi sumber daya manusia.

2. Evaluasi - evaluasi kinerjaInformasi penting harus dimutakhirkan secara periodik meliputi keahlian - keahlian dan bakat pegawai, tingkat kinerja saat ini, 
dan potensi pertumbuhannya. Organisasi memerlukan informasi yang sahih untuk membuat keputusan - keputusa perencanaan jangka panjang menyangkut individu - individu yang memiliki potensi promosi.

3. Maklumat - maklumat perubahan personalia, Organisasi telah mengembangkan blangko sederhana yang disebut maklumat perubahan personalia (personnel change notice), dimana penyelia diminta melengkapi dan mengirimkannya ke bagian sumber daya manusia.

4. Tindakan indisipliner -Inforrmasi yang bersangkut paut dengan tindakan disipliner juga diperlukan dalam sistem informasi sumber daya manusia. Beberapa organisasi menggunakan formulir ini kepada pegawai, kepada wakil serikat kerja, dan kepada bagian sumber daya manusia.

5. Data daftar gaji - Sistem informasi sumber daya manusia kadang - kadang berisi riwayat .

\section{METODE PENELITIAN}

Dalam pemecahan masalah pada suatu penelitian diperlukan suatu teknik atau cara mencari, memperoleh, mengumpulkan dan mencatat data agar mendapatkan suatu kebenaran data-data yang akan diperoleh dengan menggunakan metode penelitian. Menurut Sugiyono (2009:2), menyatakan bahwa metode penelitian pada dasarnya merupakan cara ilmiah untuk mendapatkan data dengan tujuan dan kegunaan tertentu.

\section{Desain Penelitian}

Metode penelitian yang digunakan dalam penelitian ini adalah metode deskriptif dan metode asosiatif. Menurut Bambang S.Soedibjo (2013: 7), metode deskriptif dilakukan oleh peneliti untuk mengetahui nilai variabel mandiri baik satu atau lebih variabel tanpa membuat perbandingan atau dihubungkan dengan variabel lainnya. Sedangkan metode asosiatif digunakan untuk melihat hubungan antara dua variabel atau lebih variabel, Bambang S.Soedibjo (2013: 8). Melalui metode asosiatif dapat dibangun suatu teori yang bisa berfungsi untuk menjelaskan, meramalkan atau mengendalikan suatu gejala tertentu.

\section{Unit Analisis}

Unit analisis adalah unit yang akan digunakan untuk menjelaskan atau menggambarkan karakteristik dari kumpulan objek yang lebih besar lagi (Bambang S. Soedibjo, 2013:50). Dalam penelitian ini yang menjadi unit analisis adalah individu, yaitu pegawai PT. Raudah Utama Cianjur 


\section{Populasi dan Teknik Penarikan Sampel}

Populasi adalah sekumpulan objek yang sejenis, daftar seluruh elemen atau unit sampling dalam sebuah populasi yang akan dijadikan sampel (Bambang S.Soedibjo, 2013: 126). Populasi dari penelitian ini adalah pegawai yang berjumlah 30 Orang. Teknik penarikan sampel dalam penelitian ini menggunakan sensus atau sampling jenuh, karena "sampling jenuh adalah teknik penentuan sampel bila semua anggota populasi digunakan sebagai sampel" (Sugiyono, 2011: 68).

\section{Metode Pengumpulan Data}

Metode pengumpulan data menurut Bambang S. Soedibjo (2013:111) merupakan bagian integral dari disain penelitian. Tersedia berbagai metode pengumpulan data dengan segala kelebihan dan kekurangannya, secara garis besar metode pengumpulan data ini terdiri dari wawnncara, kuesioner dan observasi

Data yang digunakan dalam penelitian ini adalah data primer, yaitu informasi yang diperoleh pertama kali oleh peneliti menyangkut variabel yang menjadi tujuan utama penelitian (Bambang S. Soedibdjo, 2013:108).

\section{Operasional Variabel}

Variabel didefinisikan agar terdapat kesamaan persepsi dalam mengkaji konsep yang sedang diteliti. Definisi operasional merupakan definisi konkrit atau spesifik dari konsep atau konstruk yang akan diukur (Bambang S. Soedibjo, 2013: 59) . Dalam penelitian ini terdapat dua variabel, yaitu variabel independen (bebas) dan variabel dependen (terikat). Variabel independen atau varibel $X$ adalah Sistem infomasi Sumber Daya Manusia (X1)

\section{TEMUAN DAN PEMBAHASAN}

Tabel 1. Uji Validitas Instrumen

\begin{tabular}{cclc}
\hline Variabel & No & \multicolumn{1}{c}{ Indikator } & r \\
\hline Sistem & 1 & Data diperoleh secara digital & 0,444 \\
Informasi & 2 & Proses pengambilan data & 0,497 \\
Sumber Daya & 3 & Penyimpanan data & 0,585 \\
Manusia & 4 & Digitalisasi data & 0,493 \\
& 5 & Metode validasi & 0,655 \\
& 6 & Data yang digunakan sudah valid & 0,515 \\
& 7 & Data dianalisis dengan metode yang tepat & 0,588 \\
& 8 & Hasil analisis dapat dipahami & 0,386 \\
& 9 & Keputusan atasan berdasarkan data & 0,390 \\
& 10 & Keputusan yang diambil tepat sasaran & 0,386 \\
\hline Kinerja & 1 & Kerapihan & 0,640 \\
& 2 & Ketelitian & 0,613 \\
\hline
\end{tabular}




\begin{tabular}{cclc}
\hline Variabel & No & Indikator & r \\
\hline 4 & Biaya yang dikeluarkan & 0,525 \\
5 & Item pekerjaan & 0,465 \\
6 & Waktu yang digunakan & 0,634 \\
7 & Sesuai uraian jabatan & 0,357 \\
8 & Sesuai target kerja & 0,488 \\
9 & Menyelesaikan pekerjaan & 0,556 \\
& 10 & Melakukan kewajiban & 0,361 \\
\hline
\end{tabular}

Dari Tabel di atas diketahui bahwa keseluruhan soal yang diajukan dalam kuesioner sebagai instrument penelitian adalah valid nilai koefisien bernilai lebih dari 0,3 atau dengan kata lain nilai kritis yang ditentukan adalah 0,3 .

\section{Uji Reliabilitas}

Uji reliabilitas dilakukan untuk melihat stabilitas dan konsistensi hasil pengukuran. Dalam uji reliabilitas yang dilihat adalah sifat alat ukurnya. Alat uji yang digunakan dalam penelitian ini adalah uji alpha $(\alpha)$ Cronbach's. Uji ini dilakukan untuk melihat konsistensi responden dalam menjawab semua butir pernyataan. Meskipun butirbutir ini independen akan tetapi apabila mengukur konsep yang sama, butir-butir ini akan berkorelasi antara satu dengan yang lainnya (Bambang S Soedibjo, 2013:83). Menurut Sekaran (2003) dalam Bambang S. Soedibjo (2013:86) dalam banyak kasus alpha $(\alpha)$ Cronbach's dapat dipandang sebagai indeks yang cukup sempurna dalam menilai reliabilitas konsistensi antar butir. Adapun rumus alpha $(\alpha)$ Cronbach's adalah sebagai berikut:

Semakin besar koefisien alpha Cronbach's atau mendekati angka 1, maka semakin reliabel alat ukur tersebut. Seperti yang diuraikan sebagai berikut: Jika nilai $\alpha<0,6$ maka Realibilitas kurang baik, jika nilai $\alpha>0,7$ Realibitas layak dan jika nilai $\alpha>0,8$ maka Realibitas baik(Bambang S. Soedibjo,2013:86)

Untuk memudahkan dalam mengolah data penulis menggunakan Software Statistical Product and Service Solution (SPSS)Versi 20. Hasil Uji Reliabelitas diuraikan sebagai berikut:

Tabel 2. Uji Reliabilitas

\begin{tabular}{lcc}
\hline \multicolumn{1}{c}{ Variabel } & 尔 & Keterangan \\
\hline Sistem Informasi SDM & 0,638 & Layak \\
Kinerja & 0,661 & Layak \\
\hline
\end{tabular}

Dari table di atas diketahui bahwa nilai alpha Cronbach's adalah layak untuk variable X (Sistem Informasi SDM) dan nilai alpha Cronbach's adalah layak. Untuk variable $\mathrm{Y}$ (Kinerja). 


\section{Analisis Deskriptif}

Dalam penelitian ini analisis yang diambil adalah analisis deskriptif kajian. Deskriptif dilakukan untuk mengetahui dan menjelaskan variable-variabel dari sebuah situasi dan keadaan. Menurut Bambang Seodibjo (2013:144) informasi yang dihasilkan dari kajian deskriptif yang dapat membantu kita adalah : Pada penelitian variabel (X1) Sistem Informasi Sumber Daya Manusia dan Kinerja Pegawai (Y), datanya merupakan data ordinal, sehingga untuk mencari nilai bobot standar dapat digunakan dengan mencari panjang rentang bobot kelima skala, adapun langkahnya sebagai berikut :

$$
\begin{aligned}
& \text { Rentang }=\frac{\text { Bmaks }- \text { Bmin }}{5} \\
& \text { Rentang }=\frac{(30 \times 5)-(30 \times 1)}{5}=24
\end{aligned}
$$

Kemudian pembobotan dibagi ke dalam 5 (lima) tingkatan berdasarkan pengklasifikasian diatas, dimulai dari tingkatan terendah ketingkatan tertinggi dengan panjang rentang di atas yaitu klasifikasi nilai bobot standar yang dihasilkan sebagai berikut:

Tabel 3. Nilai Bobot Standar

\begin{tabular}{lrrr}
\hline Buruk & 30 & - & 53 \\
\hline Tidak Baik & 54 & - & 77 \\
\hline Cukup & 78 & - & 101 \\
\hline Baik & 102 & - & 125 \\
\hline Sangat Baik & 126 & - & 150 \\
\hline
\end{tabular}

\section{Analisis Asosiatif}

Analisis Asosiatif dalam penelitian ini digunakan analisis Regresi linear, berserta koefisien determinasi yang bertujuan untuk mengetahui pengaruh ataupun juga hubungan antara dua variabel atau lebih, penelitian ini memiliki tingkatan yang lebih tinggi dibandingkan dengan deskriptif, karena dengan penelitian ini dapat dibangun suatu teori yang dapat berfungsi untuk menjelaskan, meramalkan dan mengontrol suatu gejala.Untuk melakukan analisis data maka penulis menggunakan analisis regresi linear berganda. Analisis regresi linear berganda yang di gunakan oleh penulis, meliputi, uji Asumsi Klasik, (Sugiyono, 2012:277). Bila dijabarkan secara matematis bentuk persamaan dari regresi linier berganda adalah sebagai berikut:

$$
\mathrm{Y}=\beta 0+\beta 1 X
$$

\section{Keterangan :}

$\mathrm{Y}=$ Variabel dependen yang diprediksikan atau Kinerja Pegawai

$X=$ Variabel independen atau Sistem Informasi Manajemen 
$\beta 1=$ Koefisien regresi Sistem Informasi Manajemen

$\beta 0=$ Konstanta

\section{Koefisien Determinasi}

Menurut Bambang S Soedibjo (2013:27-228) salah satu kelemahan dari $\mathrm{R}^{2}$ adalah jika ada penambahan variabel independen kedalam model, maka nilai SSE akan menurun,akibatnya nilai $R^{2}$ akan mendekati satu, meskipun variabel yang di tambahkan tidak mempunyai hubungan dengan y. akibatnya kita bisa membuat kesimpulan yang menyesatkan. Oleh karena itu, salah satu cara yang dapat di lakukan adalah dengan menggunakan apa yang di sebut sebagai $\mathrm{R}^{2}$ yang di sesuaikan (adjusted $R$-square) rumus untuk menghitung $R^{2}$ yang di seseuaikan adalah:

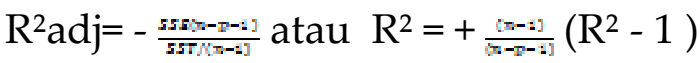

\section{Hasil Penelitian}

Penelitian menunjukkan hasil bahwa skor jawaban responden pada variable Sistem Informasi menunjukkan hasil sebesar 118,5 yang berarti baik.Adapun jawaban responden yang nilai skornya berada di bawah rata-rata adalah proses pengambilan data dari sumber data, penyimpanan data, digitalisasi data, metode validasi, analisis data dan pengambilan keputusan

Sedangkan skor jawaban responden pada variable kinerja adalah sebesar 128,3 yang berarti sangat baik.Kriteria penilaian tersebut didasarkan pada table 6 di atas. Jawaban responden yang nilai skornya lebih rendah dari nilai rata-rata jawaban responden adalah Ketelitian dalam bekerja, banyak biaya yang dikeluarkan selama proses kerja, bekerja sesuai uraian jabatan dan proses penyelesaian pekerjaan.

Secara asosiatif hasil penelitian diuraikan sebagai berikut:

Tabel 4. Penghitungan analisis regresi linear

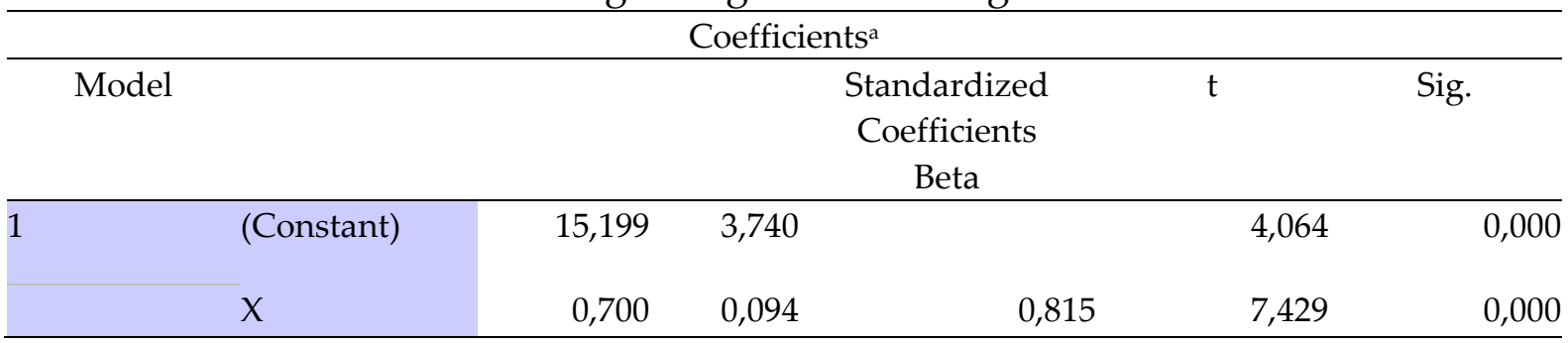

Dari table di atas menunjukkan hasil bahwa persamaan regresi yang terbentuk adalah $Y=15,199+0,700 X$. Hal ini berarti bahwa :

1. Konstanta sebesar 15,199 artinya jika Sistem informasi manajemen sumber daya manusia $(X)$ nilainya adalah 0 , maka kinerja $\left(Y^{\prime}\right)$ nilainya positif yaitu sebesar 0,700 
2. Koefisien regresi variabel sistem informasi manajemen $(X)$ sebesar 0,700 ; artinya jika sistem informasi manajemen sumber daya manusia mengalami mengalami perbaikan sebanyak satu satuan maka kinerja (Y) akan mengalami peningkatan sebesar 0,700 satuan.

3. Koefisien bernilai positif artinya terjadi hubungan positif antara sistem informasi manajemen dengan kinerja, semakin baik sistem informasi manajemen sumber daya manusia maka semakin meningkatkan kinerja.

Adapun besarnya pengaruh variable sistem informasi manajemen sumber daya manusia $(X)$ terhadap kinerja $(Y)$ ditunjukkan pada table di bawah ini:

Tabel 8 Besarnya pengaruh sistem informasi manajemen terhadap kinerja

\begin{tabular}{lcccc}
\hline \multicolumn{5}{c}{ Model Summary } \\
\hline Model & $\mathrm{R}$ & $\mathrm{R}$ Square & $\begin{array}{c}\text { Adjusted R } \\
\text { Square }\end{array}$ & $\begin{array}{c}\text { Std. Error of the } \\
\text { Estimate }\end{array}$ \\
\hline 1 & $.815^{\mathrm{a}}$ & 0,663 & 0,651 & 2,57442 \\
\hline
\end{tabular}

Dari table di atas diketahui bahwa nilai R Square adalah 0,663 hal ini berarti bahwa sistem informasi manajemen sumber daya manusia berpengaruh sebesar $66,3 \%$ terhadap kinerja.

\section{KESIMPULAN DAN SARAN}

Dari hasil penelitian menunjukkan terdapat pengaruh positif variable Sistem informasi Manajemen sumber daya manusia terhadap kinerja pada PT. Raudah Cianjur. Besarnya pengaruh Sistem informasi Manajemen sumber daya manusia terhadap kinerja adalah $66,3 \%$. Meskipun demikian secara kualitatif masih terdapat kelemahan pada sistem informasi manajemen sumber daya manusia berupa proses pengambilan data dari sumber data, penyimpanan data, digitalisasi data, metode validasi data serta analisis data dan pengambilan keputusan. Kelemahan pada kinerja adalah Ketelitian dalam bekerja, banyak biaya yang dikeluarkan selama proses kerja, bekerja sesuai uraian jabatan dan proses penyelesaian pekerjaan.Untuk itu sebaiknya pihak perusahaan memperbaiki kondisi-kondisi tersebut.

\section{DAFTAR PUSTAKA}

Bambang S.Soedibjo, 2013. Pengantar Metode Penelitian. Universitas Nasional Pasim Bandung

Cherrington, 2007. Pengertian Manajemen. Jakarta : Bumi Aksara

Edy Sutrisno, 2009. Manajemen Sumber Daya Manusia. Jakarta : Kencana

Harold Koontz, 2007. Manajemen. Jilid 2. Terjemahan Gunawan Hutaruk Jakarta:Penerbit Erlangga. 
Ike Rahmawati Kusdyah, 2008. Manajemen Sumber Daya Manusia. Yogyakarta Andi Jimmy Rusjiana. 2016. Pengaruh Sistem Informasi SDM terhadap Kinerja Karyawan di PT Rabanni Bandung. Journal Komputer dan Bisnis Vol. 10 No 1 Juni 2016, 21-29

Khaerul. Umam. 2010. Perilaku Organisasi. Bandung: Pustaka Setia

James A.F. Stoner dalam HB. Siswanto, 2009. Manajemen. Edisi Bahasa Indonesia, Penerbit PT. Prehalindo

Marihot Manulang , 2009. Dasar-Dasar Manajemen. Gadjah Mada University Press.

Malayu, S.P. Hasibuan, 2012. Manajemen Sumber Daya Manusia. Jakarta : PT. Bumi Aksara.

Malayu, S.P. Hasibuan, 2010. Manajemen Sumber Daya Manusia. Jakarta : PT. Bumi Aksara.

Malayu, S.P. Hasibuan, 2012. Manajemen Sumber Daya Manusia. Jakarta : PT. Bumi Aksara. 